\title{
First record of Scalibregma celticum (Annelida: Polychaeta: Scalibregmatidae) in Italian marine waters
}

\author{
SERENA LOMIRI, DANILO VANI, PAOLO TOMASSETTI, BENEDETTA TRABUCCO, CHIARA MAGGI \\ AND ORNELLA NONNIS \\ ISPRA, National Italian Institute for Environmental Protection and Research, Via di Casalotti 300, o0166 Rome, Italy
}

\begin{abstract}
The polychaete Scalibregma celticum was recorded for the first time along the western Italian coast (Mediterranean Sea). A survey was carried out in February 2009 off the Sardinia north-east coast. Six individuals of S. celticum were collected at $40 \mathrm{~m}$ depth on a sandy substratum. In the present study they are described, pointing out the difference between $\mathrm{S}$. celticum and $\mathrm{S}$. inflatum a species more common along the Italian coast.
\end{abstract}

Keywords: Scalibregma celticum, Scalibregmatidae, Tyrrhenian Sea, Mediterranean Sea

Submitted 10 October 2011; accepted 25 October 2011

\section{INTRDDUCTIDN}

The Scalibregmatidae (Annelida: Polychaeta: Scolecida) are sedentary polychaete worms usually present in marine subtidal sediments and in some species the presence of epitokes swarming has been reported in the plankton (Clark, 1954). They are active burrowers and subsurface deposit feeders and never form tubes (Schüller \& Ebbe 2007; Snowden, 2008).

Scalibregmatidae (except for Axiokebuita species that are maggot shaped) are characterized by short bodies, anteriorly swollen; their parapodia are biramous with simple capillary chaetae both on noto- and on neuropodia; the presence of furcate chaetae is frequent. Moreover, in some genera it is possible to observe acicular spines. Mobile appendages are absent; branchiae are not always present and in some species they are branched and placed on anterior segments. The prostomium is bilobed and often in the form of frontal horns (Worsfold, 2006). The genus Scalibregma occurs with two species in the Mediterranean Sea: Scalibregma inflatum Rathke, 1843 and S. celticum Mackie, 1991.

The genus has the characteristic T-shaped prostomium bilobed or two-horned. Eyes could be present or not, depending on species. The buccal segment is achaetous and on anterior segments branched gills are present. Parapodia are small, biramous and on posterior segments dorsal and ventral cirri are present. Concerning the chaetae, they are chiefly capillaries and even if few forked chaetae could be present, crochet are absent (Day, 1967; Hayward \& Ryland, 1995).

Only the presence of $S$. inflatum is reported for Italian seawaters, which occurs in several areas, including the central Tyrrhenian Sea (Castelli et al., 2008). This species is described as cosmopolitan, exhibiting a wide depth-range distribution, associated with a muddy sand habitat (Day, 1967).

Corresponding author:

S. Lomiri

Email: serena.lomiri@isprambiente.it
Scalibregma celticum was described as a new species by Mackie (1991), studying individuals obtained from the collections of the National Museum of Wales, Cardiff (NMW), the National Museum of Scotland, Edinburgh (NMS), the Zoological Museum, Oslo (ZMO) and the Norwegian Institute of Water Research, Grimstad (NIVA), and using comparative material borrowed from the Smithsonian Institution, National Museum of Natural History, Washington, DC and the Natural History Museum of Los Angeles County. As Mackie (1991) reports S. inflatum was considered to be the most widespread scalibregmatid but he proved the presence of at least two new species, including S. celticum.

Like S. inflatum, S. celticum is reported as ubiquitous, and it can occur in coarser sediments, including gravels (Worsfold, 2006). Moreover, the two species are easy to distinguish because of the presence of eyes in S. celticum, a feature absent in S. inflatum (Worsfold, 2006). Especially the presence of this evident characteristic avoids the possibility of misidentification of these two species.

Concerning the Mediterranean area, S. celticum has been recorded from Cyprus by Cinar (2005) and the individual he found represents a new record in the Levantine Sea and in the Mediterranean Sea. This work presents the first record of S. celticum in the western central Tyrrhenian Sea, updating the geographical distribution of this species in the Mediterranean Sea.

\section{MATERIALS ANDMETHDDS}

A survey was carried out off the Sardinia north-east coast in February 2009 (Figure 1). The sampling plan foresaw 9 stations in an area of $4 \mathrm{~km}^{2}$. Samples were collected using a Van Veen grab with the area of $0.1 \mathrm{~m}^{2}$ and a capacity of $25 \mathrm{l}$.

Samples were immediately rinsed on a sieve with a mesh of $1 \mathrm{~mm}$ and the fraction retained (macrozoobenthos according to Stirn, 1982) was fixed in a $4 \%$ formaldehyde-seawater 


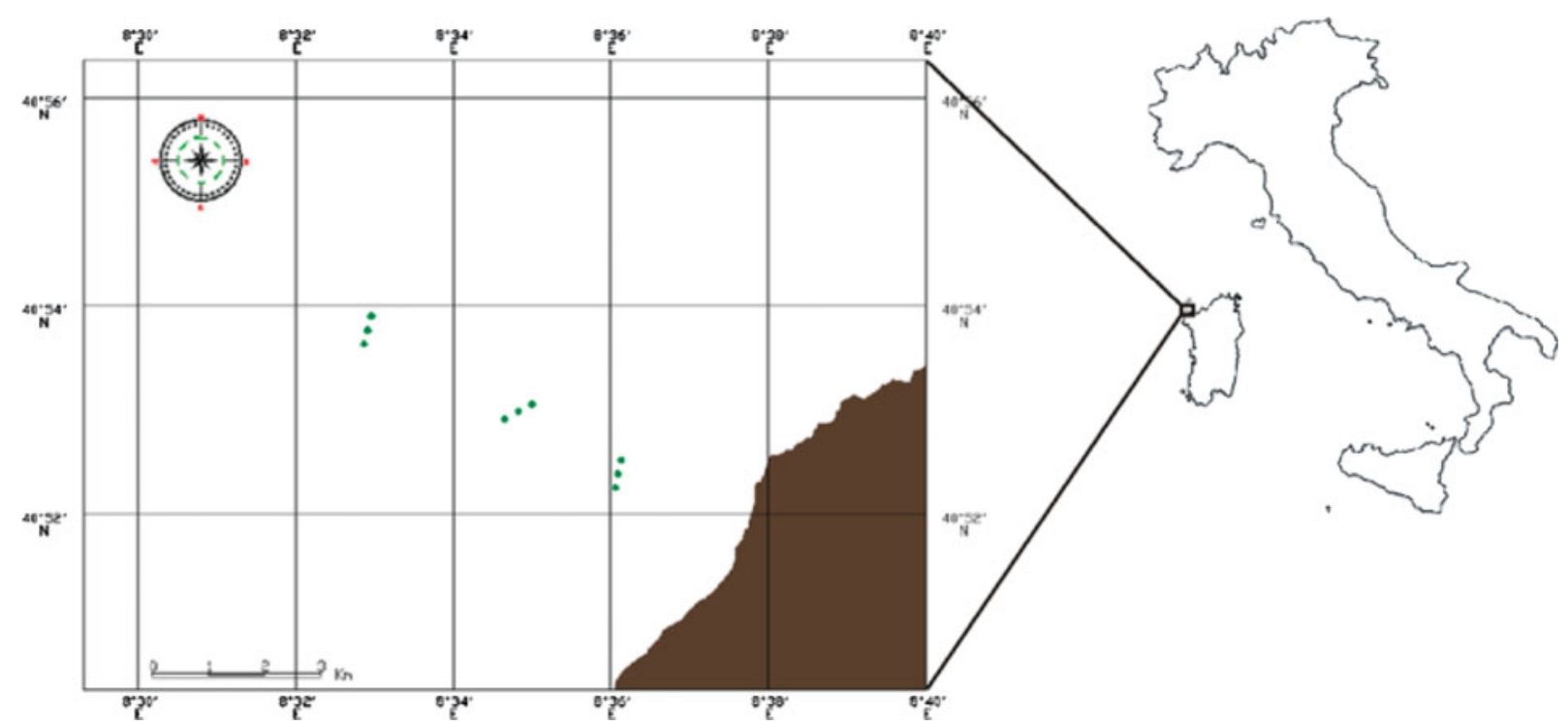

Fig. 1. Sampling area.

solution, buffered with $\mathrm{CaCO}_{3}$, then stored in polyethylene jars. Subsequently, in the laboratory, samples were sorted to different taxa and each specimen identified at the lowest taxonomic level possible. Finally, each taxon was stored in a $70 \%$ alcohol-water solution.

The S. celticum individuals were identified using 'Identification guides for the NMBAQC Scheme: 1. Scalibregmatidae (Polychaeta) from shallow seas around the British Isles' (Worsfold, 2006) and 'Scalibregma celticum new species (Polychaeta: Scalibregmatidae) from Europe, with a redescription of Scalibregma inflatum Rathke, 1843 and comments on the genus Sclerobregma Hartman, 1965' (Mackie, 1991).

\section{RESULTS}

Six individuals of $S$. celticum have been found, at a depth of $40 \mathrm{~m}$, where sediment was composed of sand for more than $75 \%$.

In Table 1 the morphological data of the six individuals of S. celticum are summarized. The individuals found are from 3 to $7 \mathrm{~mm}$ long (Figure 2A), they are transparent and the surface of the body appears divided in many equal squares. They have a T-shaped prostomium with two reddish eyes (Figure $2 \mathrm{~B}$ ), and, starting from the second or the third segment, arborescent gills are present (Figure $2 \mathrm{D}, \mathrm{E}$ ). The

Table 1. Morphological characteristics of individuals analysed.

\begin{tabular}{lllll}
\hline \multicolumn{2}{l}{ Scalibregma celticum } \\
\hline Individual & $\begin{array}{l}\text { Length } \\
\text { mm }\end{array}$ & $\begin{array}{l}\text { Width } \\
\text { mm }\end{array}$ & $\begin{array}{l}\text { First branchiferous } \\
\text { segment }\end{array}$ & $\begin{array}{l}\text { Total number } \\
\text { of segments }\end{array}$ \\
\hline A & 7 & 1 & 2nd & $33-34$ \\
B & 7 & 1 & $3 \mathrm{rd}$ & $\sim 35$ \\
C & $\sim 3.5$ & 1 & 2nd & 30 \\
D & $\sim 6$ & 1 & 3 rd & $\sim 30$ \\
E & 3 & 1 & 2nd & $\sim 25$ \\
F & 4 & 1 & $3 r d$ & $\sim 30$ \\
\hline
\end{tabular}

anterior part of the body is expanded and, in this region, parapodia are very small, not clearly noticeable, especially in individuals where the enlargement is particularly marked. The posterior part of the body is tapered and, in this region, parapodia are more developed, bigger, and dorsal and ventral cirri are present. On the pygidium five anal cirri are present (Figure $2 \mathrm{C}$ ). Concerning the chaetae, on all parapodia blunt chaetae are present (Figure $2 \mathrm{~F}$ ) and, after the first parapodia also appear furcate chaetae. These are smaller than the capillaries and often hard to detect since they are covered by the capillaries.

\section{DISCUSSIDN}

The presence of $S$. inflatum is reported in Italian sea waters (Castelli et al., 2008). According to Mackie (1991), S. celticum can be identified by the presence of some features: the most obvious is the presence of eyes. Scalibregma celticum has a single pair of subdermal eyes (Fig. 6), ranging from dark brown to black, placed on posterolateral margins of the prostomium. This feature distinguishes it from S. inflatum, in which eyes are lacking, and that is present in central Tyrrhennian Sea (Castelli et al., 2008). Then it is possible to observe short blunt spines in parapodia of both setigers 1 and 2, while in S. inflatum there are no blunt chaetae in anterior parapodia (Worsfold, 2006). Other differences are an expanded hood-like peristomium obscuring eyes and the posterior part of prostomium, an upper lip of the mouth that is medially folded and the presence of smaller epidermal pads above the notopodia and across the dorsum of setigers 1-5. With regard to the size, $S$. celticum is smaller than $S$. inflatum: S. celticum lengths are reported from 2.5 to $22 \mathrm{~mm}$ for 30-48 segments, for $S$. inflatum the length-range reaches $37 \mathrm{~mm}$ for 23-64 segments (Mackie, 1991). The features observed in the individuals found by us perfectly match the description proposed by Mackie (1991), allowing their identification as $S$. celticum.

Both the European Register of Marine Species (ERMS) and the World Register of Marine Species (WoRMS) reported the 

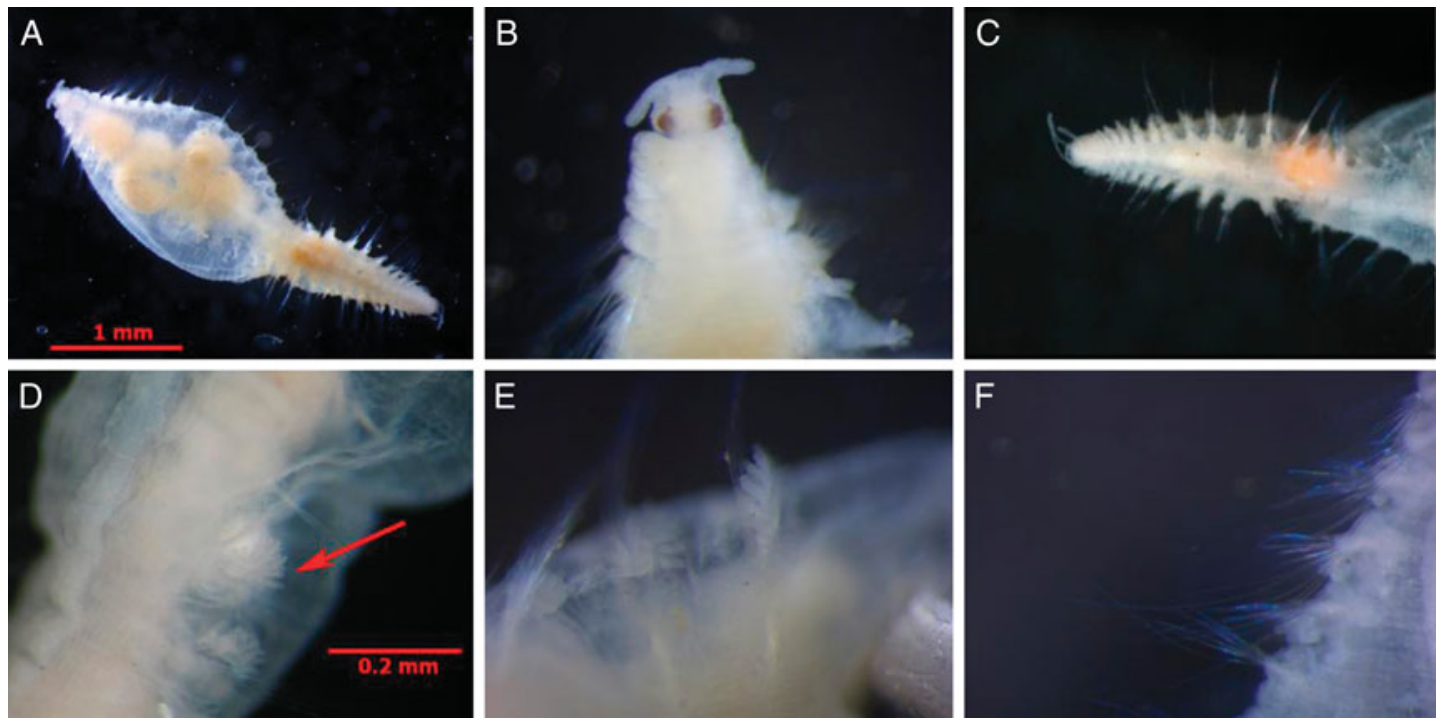

Fig. 2. Scalibregma celticum: (A) entire body; (B) prostomium with eyes; (C) pygidium; (D, E) arborescent gills; (F) chaetae.

distribution of $S$. celticum in the European area that includes the Mediterranean Sea Area (Costello et al., 2008; Appeltans et al., 2011). Nevertheless the species is not reported in the 'Italian Checklist of Marine Fauna' (Castelli et al., 2008) and our record can be reported as the first record in Italian sea waters.

The worldwide distribution of S.celticum is reported in Figure 3. In this image yellow dots are related to the known distribution of $S$. celticum, as reported on the Ocean Biogeographic System website (Vanden Berghe, 2007). Red dots update the known distribution because they are related to Çinar's (2005) record in Cyprus sea waters and to our record in Italian sea waters.

Probably the species is not mentioned in the Italian checklist for several reasons including difficulty in finding

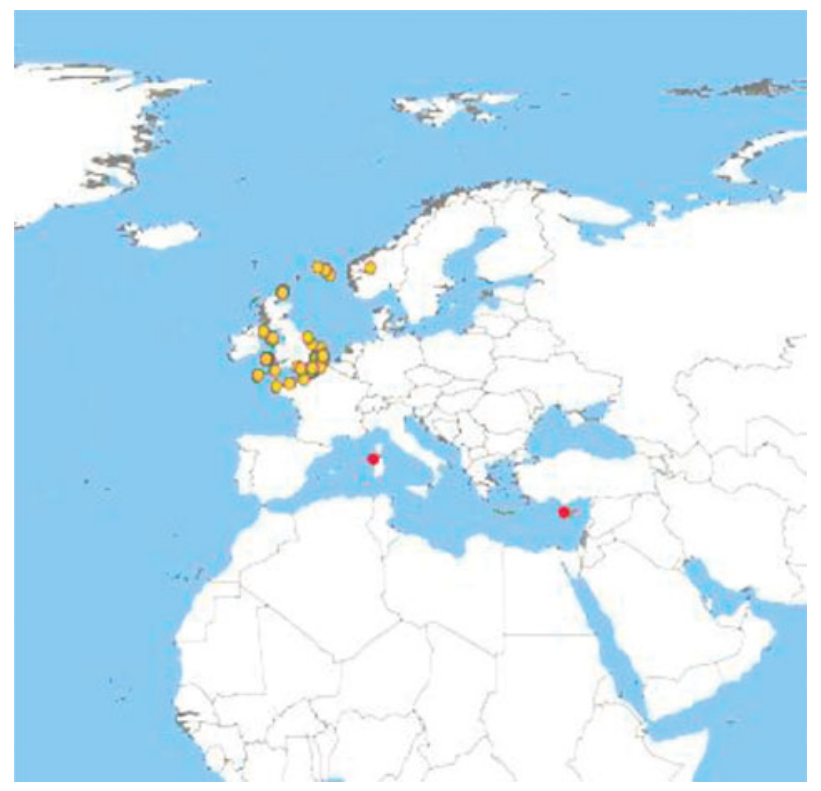

Fig. 3. Worldwide distribution of Scalibregma celticum: yellow dots represent the distribution as reported on the iOBIS website (Vanden Berghe, 2007); red dots represent Cinar's (2005) record in the Levantine Sea and our record in the Tyrrhenian Sea. individuals, as well as a lack of investigation, particularly in the area analysed in this work. The two species of Scalibregma are easy to distinguish mainly due to the presence/absence of eyes as well as the presence/absence of blunt chaetae in anterior parapodia. For these reasons we can suppose that misidentification is to be excluded. Besides, the examination of the individuals found confirms the original description provided by Mackie (1991). All the distinctive characteristics of $S$. celticum have been identified in order to allow a clear distinction between this species and S. inflatum already reported in the 'Italian Checklist of Marine Fauna' (Castelli et al., 2008). It is premature, at this stage, to give an opinion about the origin of the species or its possible dynamics of colonization/expansion. The record of other individuals, eventually coming from other areas of the Mediterranean, will enable more detailed studies, possibly using also genetic techniques, in order to make hypotheses about the origin and the colonization pattern of the species.

\section{REFERENCES}

Appeltans W., Bouchet P., Boxshall G.A., Fauchald K., Gordon D.P., Hoeksema B.W., Poore G.C.B., van Soest R.W.M., Stöhr S., Walter T.C. and Costello M.J. (eds) (2011) World Register of Marine Species. Available at http://www.marinespecies.org (accessed 10 October 2011).

Castelli A., Bianchi C.N., Cantone G., Çinar M.E., Gambi M.C., Giangrande A., Iraci Sareri D., Lanera P., Licciano M., Musco L., Sanfilippo R. and Simonini R. (2008) Annelida Polychaeta. In Relini G. (ed.) Checklist della Flora e Fauna dei Mari Italiani (parte I) Biologia Marina Mediterranea 15 (Supplement), 323-373.

Çinar M.E. (2005) Polychaetes from the coast of northern Cyprus (eastern Mediterranean Sea) with two new records for the Mediterranean Sea. Cahier de Biologie Marine 46, 143-159.

Clark R.B. (1954) Pelagic swarming of Scalibregmatidae (Polychaeta). Report of the Scottish Marine Biological Association 1952-53, 20-22.

Costello M.J., Bouchet P., Boxshall G., Arvantidis C. and Appeltans W. (2008) European Register of Marine Species. Available at http://www. marbef.org/data/erms.php (accessed 10 October 2011). 
Day J.H. (1967) A monograph on the Polychaeta of southern Africa, Part 1: Errantia. London: Trustees of the British Museum (Natural History), $456 \mathrm{pp}$.

Hayward P.J. and Ryland J.S. (eds) (1995) Handbook of the marine fauna of north-west Europe. Oxford: Oxford University Press, 800 pp.

Mackie A.S.Y. (1991) Scalibregma celticum new species (Polychaeta: Scalibregmatidae) from Europe, with a redescription of Scalibregma inflatum Rathke, 1843 and comments on the genus Sclerobregma Hartman, 1965. Bulletin of Marine Science 48, 268-276.

Schüller M. and Ebbe B. (2007) Global distributional patterns of selected deep-sea Polychaeta (Annelida) from the Southern Ocean. Deep-Sea Research Part II: Topical Studies in Oceanography 54, 1737-1751.

Snowden E. (2008) Scalibregma inflatum. A polychaete. Marine Life Information Network: Biology and Sensitivity Key Information Sub-programme. Plymouth: Marine Biological Association of the United Kingdom. Available from: http://www.marlin.ac.uk/speciesin (accessed 26 January 2011).
Stirn J. (1982) Manuel des methodes de recherche sur l'environnement aquatique. FAO Document Technique sur les pêches, no.209, 75 pp.

Vanden Berghe E. (ed.) (2007) The Ocean Biogeographic Information System: web pages. Available at http://www.iobis.org (accessed 10 October 2011).

and

Worsfold T. (2006) Identification guides for the NMBAQC Scheme 1. Scalibregmatidae (Polychaeta) from shallow seas around the British Isles. Porcupine Marine History Society Newsletter 20, 15-18.

\section{Correspondence should be addressed to:}

S. Lomiri

ISPRA, National Italian Institute for Environmental Protection and Research

Via di Casalotti 300, 00166 Rome, Italy

email: serena.lomiri@isprambiente.it 